\title{
ANILITICAL ECONOMIC STUDY OF MANGO YIELD IN EGYPT
}

FAIZA AHMED MOHAMED AHMED

Agric. Econ. Res. Instit- ARC, Dokki, Giza, Egypt

(Manuscript received 13 March 2018)

\begin{abstract}
$\mathrm{T}$ he research aims at identifying the current status of some economic variables of mango crop in Egypt, measuring the effect of temporal and geographic changes on mango productivity using two-way variance analysis, Duncan method for multiple range testing, the ability to comply with export orders through the process of production and export stability of Egypt and the competing countries. It was found that the average of mango area during the period (2014-2016) was about 219 thousand feddans representing about $16.2 \%$ of total fruit area with an average productivity of about 4.2 tons per feddan. The annual average value of agricultural, plants, fruits and mango production was about 18.5, 108.5, 189.7 and 2 billion pounds during the previous period. The annual average of productive area, feddan productivity and production of mango during the period (20002016) was 136.4 thousand feddans, 4.2 tons per feddan and 560.3 thousand tons respectively. The annual increase in area and production amounted to about 11,28 thousand feddans, 41,68 thousand tons respectively, while there is a significant annual decrease in productivity of the crop during the period of research about 0.05 tons per feddan. The annual average consumption and exports of mango was 544.8 thousand tons, 6.4 thousand tons respectively, representing consumption of about $97.51 \%$ of mango production, while exports represented about $0.94 \%, 0.97 \%$ of the annual average For both mango production and consumption, there is an annual increase in consumption and exports of mango during the study period amounted to about 39.53, 1.08 thousand tons respectively. There was a statistically significant difference between the feddan productivity of mango during the period (2012 - 2016). The feddan productivity divided into three groups, the highest productivity was about 4.40 tons in 2014. There is also a statistically significant difference between the feddan productivity average of mango during the period of study and for different governorates also, showed that the province of Nubaria was the highest productivity, where the productivity average was about 7.31 tons / feddan during the study period. The study examined the extent of production and export stability of Egypt and the mango exporting countries during the study period, indicating that there is an advantage for Egypt in the production stability of mango, but it does not enjoy the same advantage in export stability despite the instability of production. This may be due to an imbalance in the production system for export, or a defect in the export system itself. Conversely, Mexico, Peru and the Netherlands have an advantage in export stability. This may be due to the fact that these countries pursue good export policies based on their shareholding Market.
\end{abstract}




\title{
دراسة تحليلية اقتصادية لإنتاجية محصول الماتجو في مصر
}

\author{
فايزة أحمد محمد أحمد \\ معرد بحوث الاقتصاد الزراعى - دقى - جيزة - مصر
}

\begin{abstract}
مقدمة
يعتبر المانجو من ثمار الفواكه التي تزرع في المناطق الإستوائية وتحت الإستو ائية، وثمار ها

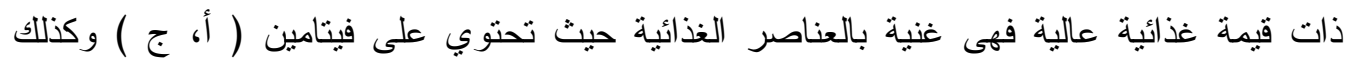

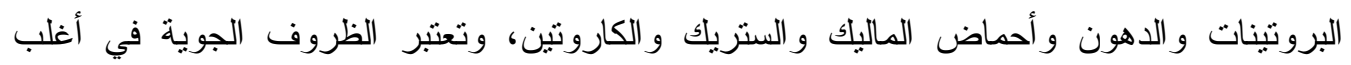

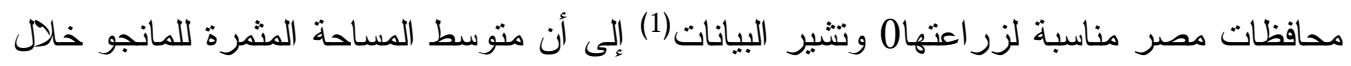
الفترة (2016-2014) بلغ حوالي 219 ألف فدان يمتل نحو 16,2\% من منوسط إجمالي مساحة الفاكهة المثمرة، أما الإنتاجية الفدانية فقد بلغ متوسطها خلال نفس الفترة حوالي 4,2 طن للفدان، وتعتبر هذه الإنتاجية منخفضة إذا ماقورنت بمتوسط الإنتاجية في دول أخرى متل ( الهند، باكستان،

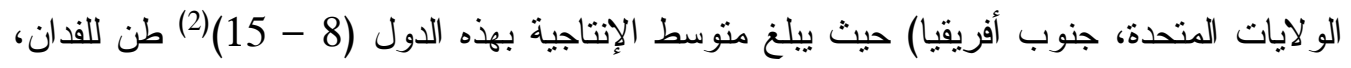

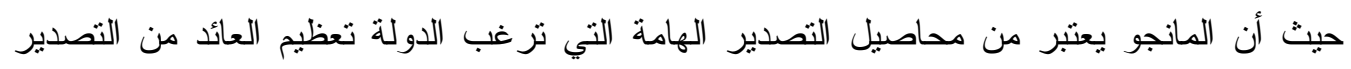

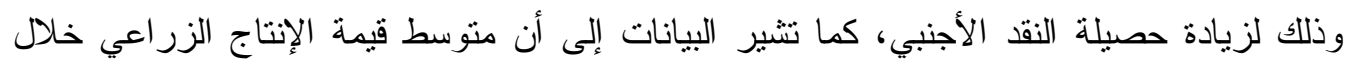

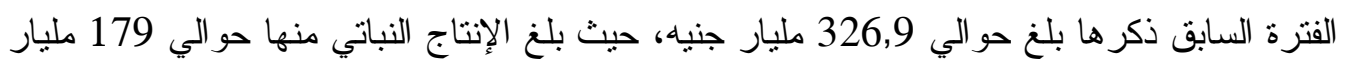

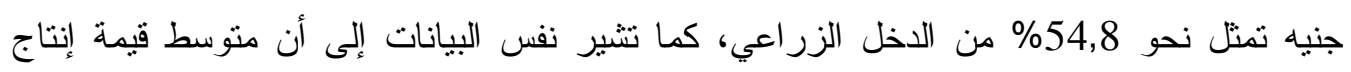

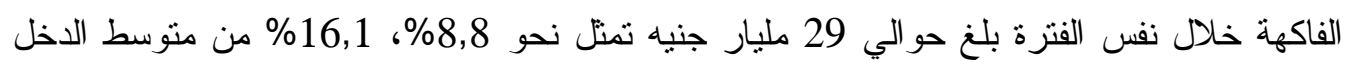
الزراعي والنباتي على الترتيب، وتبين أيضاً خلال هذه الفترة أن متوسط قيمة إنتاج المانجو بلغ

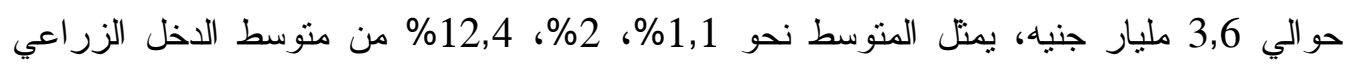
و النباتي و الفاكهى على الترتيب.
\end{abstract}

\section{مشكلة البحث}

تكمن المشكلة البحثية في إنخفاض الإنتاجية الفدانية للمانجو في مصر إذا ماقورنت بالإنتاجية

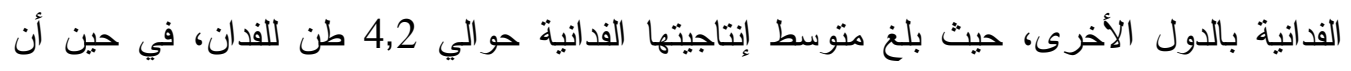
متوسط الإنتاجية في دول أخرى بلغ حو الي (15-8) طن للفدان، فضلاً عن إنخفاض الأهمية النسبية

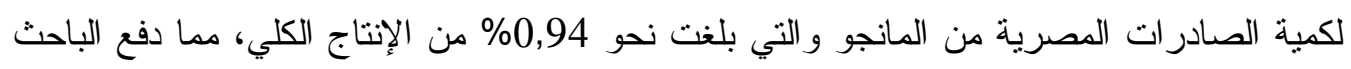

بالقيام بدر اسة هذه المشكلة ووضع بعض التوصيات لحلها. 


\section{الهزف من البحث}

يهرف البحث إلى التعرف على الوضع الراهن لبعض المتغيرات الاقتصادية لمحصول المــانجو

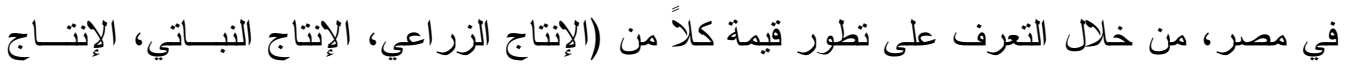

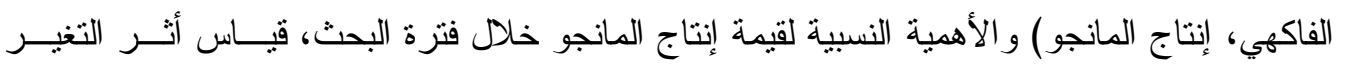

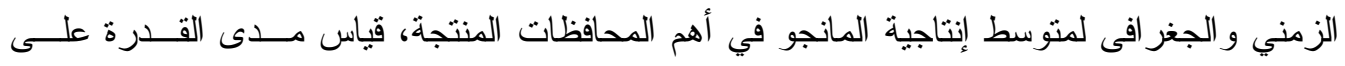
الإستقرار الإنتاجي و التصديري من خلال تقدير معاملات عدم الإســتقرار الإنتــاجي و التصــديري لمصر و الدول المنافسة لها في نفس الأسواق، و إظهار بعض المشاكل التي تؤثر على إنتاجية المانجو

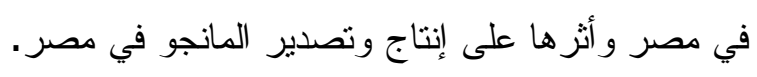
الطريقة البحثية ومصادر البيانات:

اعنمد البحث على أسلوب التحليل الإحصائي الوصفي والكمي للمتغيرات الاقتصادية موضوع البحث، بتقدير معادلات الاتجاه الزمني العام للمتغيرات الإحصائية لمحصول المانجو، و إستخدام تحليل التباين في إتجاهين واختبار معنوية الفروق بين المتوسطات باستخدام طريقة دنكان، تقدير وقياس معاملات الإستقر ار الإنتاجي و التصديري لمحصول المانجو، ومصادر البيانات الثانوية من وزارة الزراعة والجهات التابعة لها، الجهاز المركزي للتعبئة العامة و الإحصاء، وشبكة المعلومات الدولية.

تطور قيمة كلاً من الإنتاج الزراعي، النباتي، الفاكهي والمانجو في مصر 1 - تطور قيمة الإنتاج الزراعي:

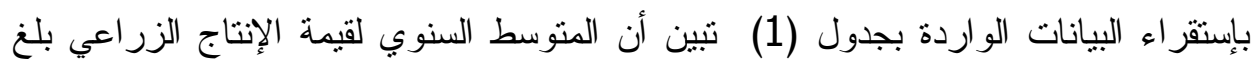

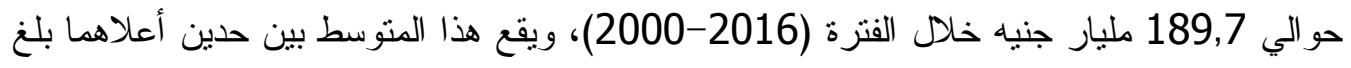

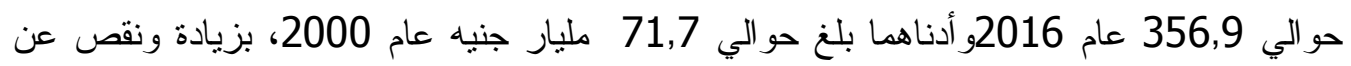

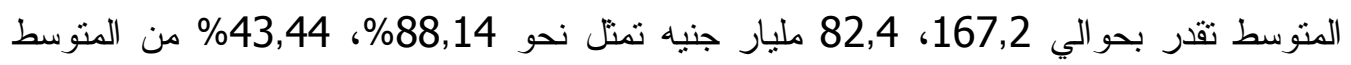
السنوي على التزتيب.

تشير معادلة الإتجاه الزمني العام بجدول (2) إلى زيادة قيمة الإنتاج الزراعي بحوالي

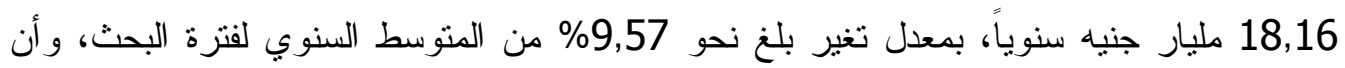
قيمة معامل التحديد بلغت نحو 98\% من التغيرات التي حدثت في قيمة الإنتاج الزر اعي خلال تلك بلك الفترة و التي يعكسها عامل الزمن و الباقي يرجع لعو امل أخرى غير مقيسة. 2- تطور قيمة الإتتاج النباتي: يتبين من جدول (1) أن المتوسط السنوي لقيمة الإنتاج النباتي خلال فترة البحث بلغ حوالي

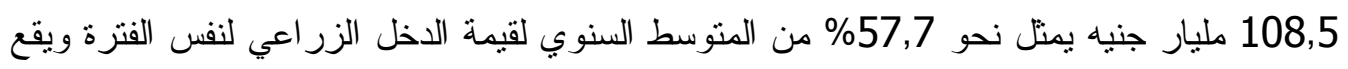

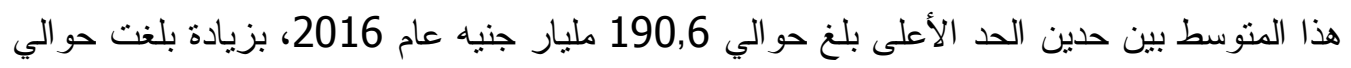
82,1 مليار جنيه تمنل نحو 75,67\% من المتوسط السنوي، أما الحد الأدنى فقد بلغ حوالي 91 مليار جنيه عام 2000 بنقص قدر بحوالي 17,5 مليار جنيه يمنل نحو 16,13\% ملئ من من المتوسط السنوي خلال فترة البحث. 
يتضح من العلاقة الإنحدارية التي تم تقدير ها بين تطور قيمة الإنتاج النباتي وعامل الزمن

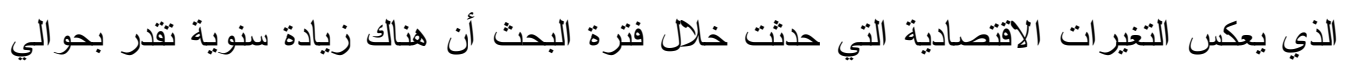
10.004 مليار جنيه بمعدل نمو سنوي بلغ نحو 9.22\% وتشير قيمة معامل التحديد إلى أن نحو 97\% من التغير ات التي حدثت في قيمة الإنتاج النباتي خلال فترة البحث ترجع للعو امل الاقتصادية

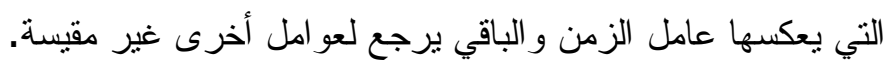

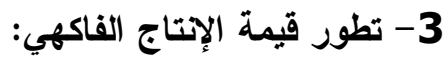

تتشير بيانات جدول (1) إلى أن المتوسط السنوي لقيمة الإنتاج الفاكهي قد بلغ حوالي 18,5 18:5 مليار جنيه يمنل نحو 10.3\%، 17.9\% من قيمة الإنتاج الزر اعي و النباتي على التزتيب خلال فترة

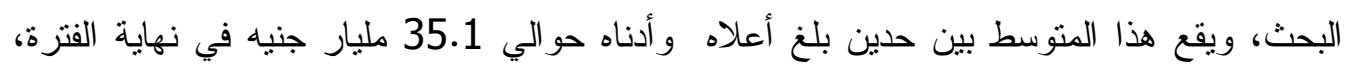

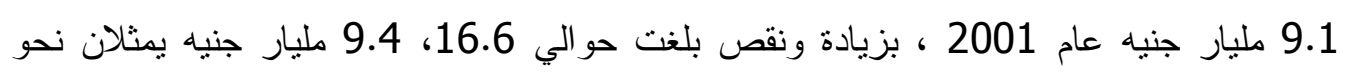
89.73\%، 50.81\% عن المنوسط السنوي لفترة البحث.

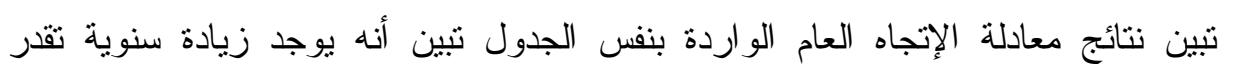

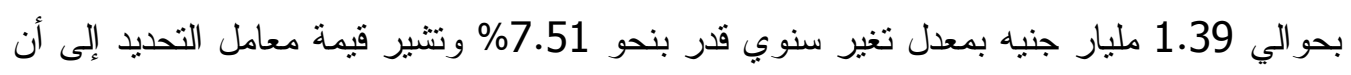

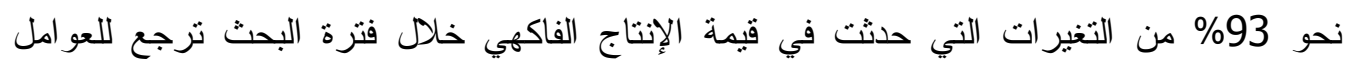

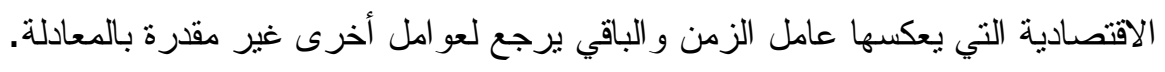
4- تطور قيمة إنتاج المانجو:

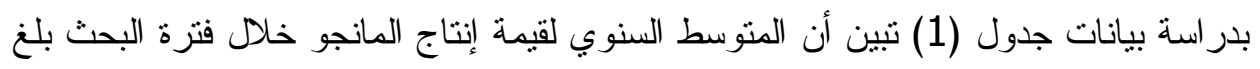

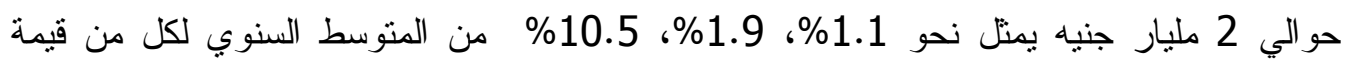

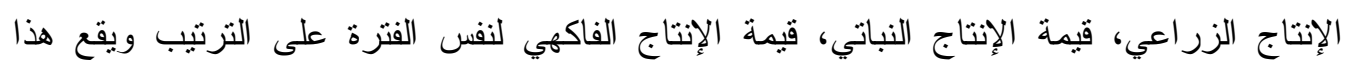

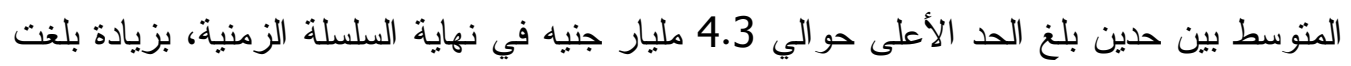
حو الي 2.3 مليار جنيه تمنل نحو 115\% من المتوسط السنوي، أما الحد الأدنى فبلغ حو الي 0.82

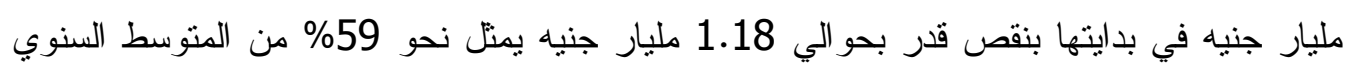

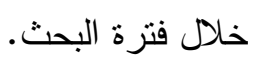




\section{جدول (1)}

تطور قيمة الإتاج الزراعي و النباتي و الفاكهة و المانجو خلال الفترة (2000- 2016) (بالمليار جنيه)

\begin{tabular}{|c|c|c|c|c|c|c|c|c|c|c|}
\hline الما النتاج & ألما & ألما & الإل الإنتاج & الإل الإنتاج & 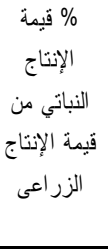 & المانتاج & الإلفاكهيم & قالنباتئي الإنتاج & الزالزئاج & السنو ات \\
\hline 8,7 & 1,9 & 1,1 & 21,4 & 13,1 & 61,2 & 0,82 & 9,4 & 43,9 & 71,7 & 2000 \\
\hline 9,9 & 2,0 & 1,2 & 20,4 & 12,2 & 59,8 & 0,90 & 9,1 & 44,7 & 74,7 & 2001 \\
\hline 8,9 & 1,8 & 1,0 & 19,8 & 11,4 & 57,5 & 0,85 & 9,6 & 48,5 & 84,3 & 2002 \\
\hline 10,0 & 2,0 & 1,1 & 19,8 & 11,4 & 57,3 & 1,1 & 11,0 & 55,5 & 96,9 & 2003 \\
\hline 10,7 & 2,0 & 1,2 & 18,6 & 10,8 & 58,2 & 1,3 & 12,1 & 65,1 & 111,8 & 2004 \\
\hline 11,6 & 2,2 & 1,3 & 19,2 & 10,9 & 56,6 & 1,6 & 13,8 & 71,9 & 127,0 & 2005 \\
\hline 14,7 & 3,1 & 1,7 & 20,8 & 11,9 & 57,1 & 2,4 & 16,3 & 78,4 & 137,4 & 2006 \\
\hline 13,0 & 2,7 & 1,5 & 20,5 & 11,8 & 57,6 & 2,4 & 18,4 & 89,9 & 156,0 & 2007 \\
\hline 9,2 & 1,5 & 0,9 & 15,8 & 9,4 & 59,1 & 1,6 & 17,4 & 109,8 & 185,7 & 2008 \\
\hline 7,4 & 1,3 & 0,7 & 17,4 & 10,0 & 57,4 & 1,4 & 18,9 & 108,7 & 189,4 & 2009 \\
\hline 7,8 & 1,4 & 0,8 & 17,4 & 9,7 & 56,1 & 1,6 & 20,4 & 117,5 & 209,4 & 2010 \\
\hline 8,2 & 1,3 & 0,8 & 15,6 & 9,2 & 59,4 & 1,9 & 23,1 & 148,5 & 250,0 & 2011 \\
\hline 9,8 & 1,6 & 0,9 & 15,9 & 9,5 & 60,1 & 2,5 & 25,5 & 160,8 & 267,4 & 2012 \\
\hline 10,9 & 1,5 & 0,8 & 13,3 & 7,8 & 58,4 & 2,4 & 22,0 & 165,03 & 282,4 & 2013 \\
\hline 12,8 & 1,9 & 1,0 & 14,6 & 8,2 & 56,0 & 3,2 & 25,0 & 171,0 & 305,4 & 2014 \\
\hline 12,2 & 1,9 & 1,0 & 15,4 & 8,5 & 55,1 & 3,3 & 27,0 & 175,5 & 318,3 & 2015 \\
\hline 12,3 & 2,3 & 1,2 & 18,4 & 9,8 & 53,4 & 4,3 & 35,1 & 190,6 & 356,9 & 2016 \\
\hline 10,5 & 1,9 & 1,1 & 17,9 & 10,3 & 57,7 & 2,0 & 18,5 & 108,5 & 189,7 & الدتو سط \\
\hline
\end{tabular}

المصدر : وزارة الزر اعة واستصلاح الأراضي، قطاع الثئون الاقتصادية، نشرة الدخل الزر اعي، أعداد مختلفة. كما يتضح من نتائج الإتجاه العام التي تم تقدير ها بين تطور قيمة إنتاج المانجو وعامل الزمن الزمن الذي يعكس التغيرات الاقتصادية التي حدثت خلال فترة البحث أن هناك زيادة سنوية تقدر بحو الي لئن

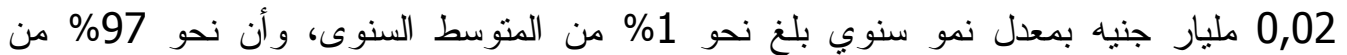
التغيرات التي حدثت في قيمة إنتاج المانجو خلال فترة البحث ترجع للعو امل الاقتصادية التي بعكسها عامل الزمن و الباقي يرجع لعو امل أخرى غير مقيسة.

جدول (2)

الاتجاه الزمني العام لتطور كلاً من قيمة الإتتاج الزراعي، النباتي،

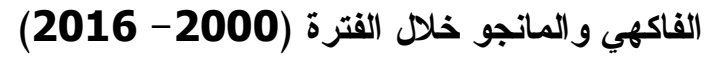

(القيمة بالمليار جنيه)

\begin{tabular}{|c|c|c|c|c|c|}
\hline المنموذج & $\begin{array}{c}\text { معدل التغير } \\
\%\end{array}$ & المتوسط & 2J & المعادلة & ال المتغير \\
\hline معنوي & 9,57 & 189,7 & 0,98 & 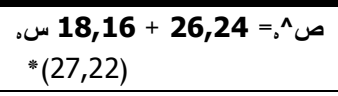 & قيمة الإتتاج الزراعي \\
\hline معنوي & 9,22 & 108,5 & 0,97 & 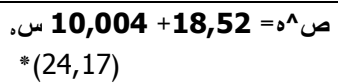 & قيمة الإتتاج النباتي \\
\hline معنوي & 7,51 & 18,5 & 0,93 & 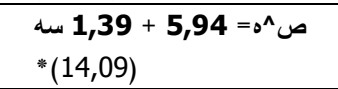 & قيمة الإتتاج الفاكهي \\
\hline معنوي & 1,00 & 2,0 & 0,75 & 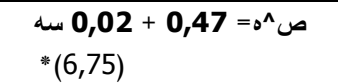 & قيمة إنتاج المانجو \\
\hline
\end{tabular}




\section{بعض المؤشرات الاقتصادية لمحصول المانجو في مصر}

1- ت تطور المساحة المثمرة:

بإستثر اء بيانات جدول (3) تبين أن المتوسط السنوي للمساحة المثرة لمحصــول المــانجو

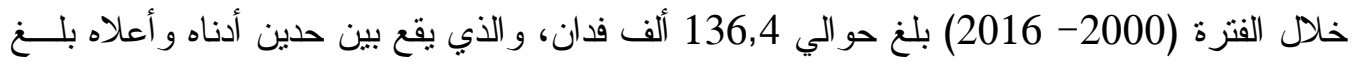
حو الي 64,4، 234 ألف فدان في بداية ونهاية الفترة، ويمثل نحو 12,3\% من المتوســـ الســنوي لإجمالي مساحة الفاكهة المثرة البالغ حو الي 1108,9 ألف فدان.

توضح معادلات الإتجاه العام بجدول (4) أن هناك زيادة سنوية في المساحة المثرة للمحسول خلال فترة البحث معنوية إحصائية بلغت حو الي 11,28 ألف فدان، بمعدل تغير بلغ نحو 8,27\% من

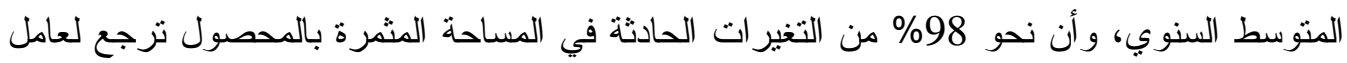
الزمن، و الباقي يرجع لعو امل أخرى غير مقيسة.

1- 1 - تطور الإتتاجية الفدانية:

تشير بيانات جدول (3) إلى أن المنوسط السنوي للإنتاجية الفدانية لمحصول المانجو خــده

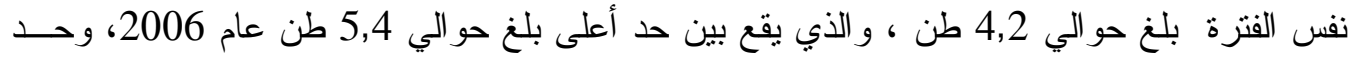

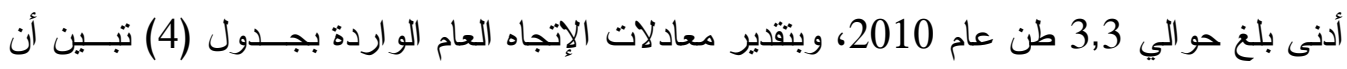

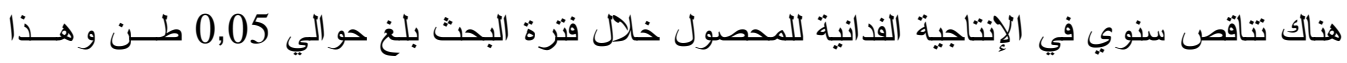

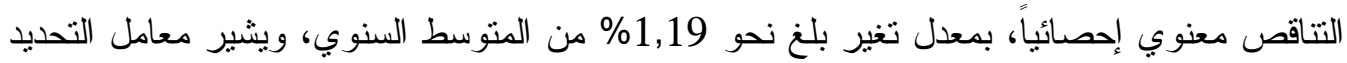

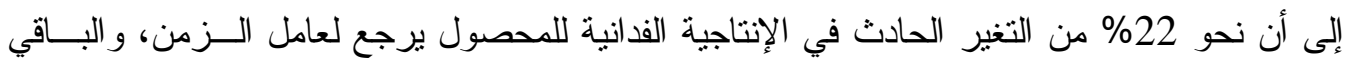
يرجع لعو امل أخرى غير مقيسة. 2- 2 تطور الإنتاج الكلي:

يوضح جدول (3) أن المتوسط السنوي للإنتاج الكلي لمحصول المانجو خلال فترة البحــث

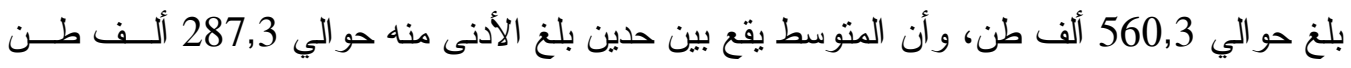

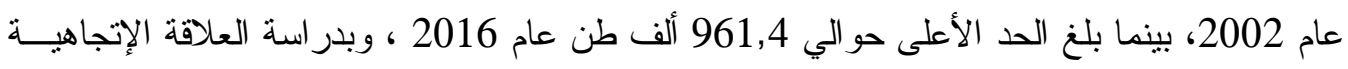

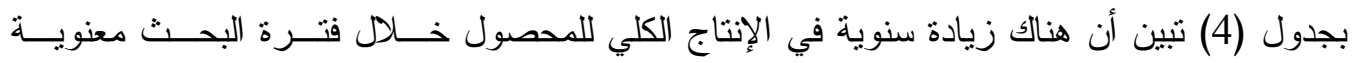

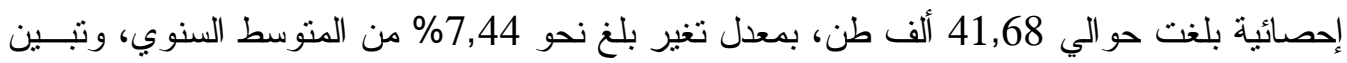

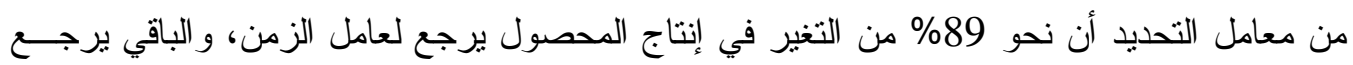
لعو امل أخرى غير مقيسة. 3-تطور الاستهلاك:

تبين من بيانات جدول (3) أن المتوسط السنوي للاستهلاك من محصول المانجو خلال فترة

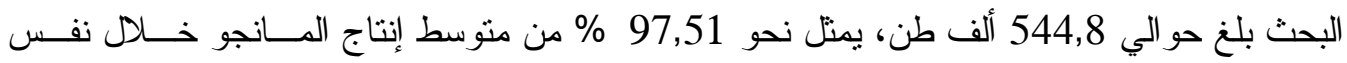

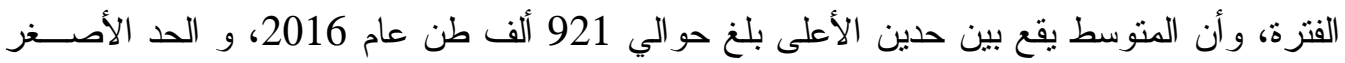
بلغ حو الي 283 ألف طن عام 2002 ـ 2002

كما توضح معادلة الإتجاه العام بجدول (4) أن هناك زيادة سنوية في الاستهلاك من هــــا

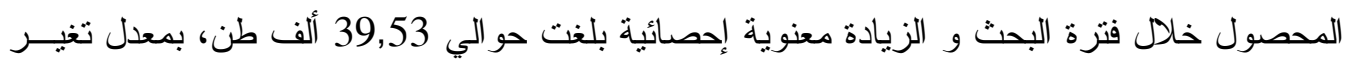




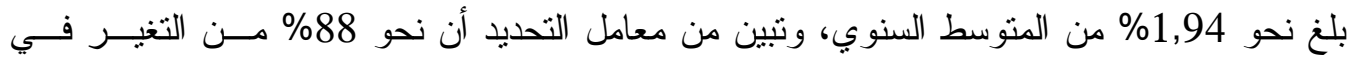
استهلاك المحصول يرجع لعامل الزمن، و الباقي يرجع لعو امل أخرى مقيسة.

جدول (3)

بعض المؤشرات الاقتصادية لمحصول المانجو بمصر خلا الفترة (2000-

\begin{tabular}{|c|c|c|c|c|c|c|c|c|c|c|}
\hline $\begin{array}{c}\text { الصادر ات } \\
\text { الاستهلاك } \\
\text { الصن }\end{array}$ & $\begin{array}{c}\text { من الإدرات } \\
\end{array}$ & $\begin{array}{c}\text { الاستهلاك } \\
\text { الإنتاج } \\
\text { الكن }\end{array}$ & الصادرات & بالألف لالك & كميةالإنتاج & الإلنتاجية & مساحة & المالألمب & الفاكألمة & البيان \\
\hline 0.47 & 0.45 & 95.02 & 1.34 & 284 & 298.9 & 4.6 & 7.2 & 64.4 & 894.3 & 2000 \\
\hline 0.30 & 0.30 & 100.15 & 0.99 & 326 & 325.5 & 4.9 & 7.3 & 66.1 & 910.5 & 2001 \\
\hline 0.30 & 0.30 & 98.50 & 0.85 & 283 & 287.3 & 4.2 & 7.4 & 68.6 & 929.3 & 2002 \\
\hline 0.15 & 0.14 & 98.81 & 0.46 & 315 & 318.8 & 4.4 & 7.8 & 73 & 933.4 & 2003 \\
\hline 0.19 & 0.19 & 98.54 & 0.7 & 370 & 375.5 & 4.6 & 8.5 & 81.4 & 958.4 & 2004 \\
\hline 0.39 & 0.38 & 98.08 & 1.58 & 409 & 417.0 & 4.2 & 9.8 & 99.4 & 1010.2 & 2005 \\
\hline 0.30 & 0.29 & 99.36 & 1.76 & 593 & 596.8 & 5.4 & 10.5 & 110.3 & 1047.1 & 2006 \\
\hline 0.47 & 0.46 & 98.99 & 2.46 & 527 & 532.4 & 4.6 & 10.8 & 115.5 & 1066.3 & 2007 \\
\hline 0.60 & 0.59 & 97.98 & 2.76 & 457 & 466.4 & 3.5 & 11.9 & 132.1 & 1108 & 2008 \\
\hline 0.63 & 0.62 & 98.24 & 3.32 & 525 & 534.4 & 3.7 & 12.9 & 145 & 1126.3 & 2009 \\
\hline 2.73 & 2.64 & 96.70 & 13.36 & 489 & 505.7 & 3.3 & 13.3 & 151.9 & 1140.2 & 2010 \\
\hline 1.36 & 1.30 & 95.97 & 7.79 & 574 & 598.1 & 3.5 & 14.4 & 169.1 & 1174.4 & 2011 \\
\hline 2.58 & 2.49 & 96.25 & 19.56 & 757 & 786.5 & 4.3 & 15.0 & 183.3 & 1220.7 & 2012 \\
\hline 0.84 & 0.81 & 96.14 & 5.74 & 685 & 712.5 & 3.5 & 15.6 & 200.9 & 1285.1 & 2013 \\
\hline 1.63 & 1.56 & 96.08 & 14.51 & 891 & 927.4 & 4.4 & 16.1 & 210.7 & 1310.7 & 2014 \\
\hline 1.89 & 1.83 & 97.06 & 16.16 & 855 & 880.9 & 4.1 & 15.7 & 212.3 & 1351.6 & 2015 \\
\hline 1.63 & 1.57 & 95.80 & 15.05 & 921 & 961.4 & 4.1 & 16.9 & 234 & 1385.4 & 2016 \\
\hline 0.97 & 0.94 & 97.51 & 6.38 & 8544. & 560.3 & 4.2 & 12.3 & 136.4 & 1108.9 & المنوسط \\
\hline
\end{tabular}

\section{4- تطور كمية الصادرات المصرية:}

يوضح جدول (3) أن المتوسط السنوي لكمية الصادر ات المصرية من محصــــول المــانجو

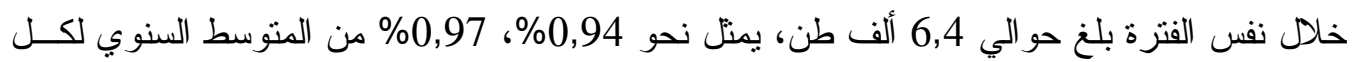
من إنتاج و استهلاك المانجو على التو الي خلال تلك الفترة، و يقع بين حدين أدناهما بلغ حو الي

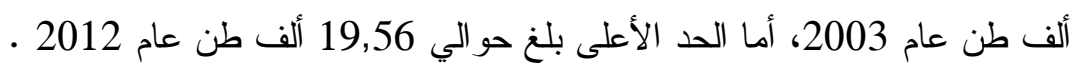

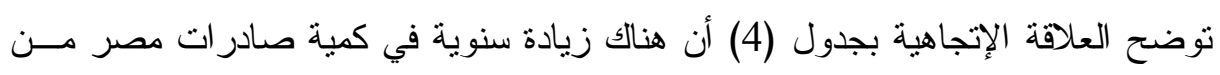

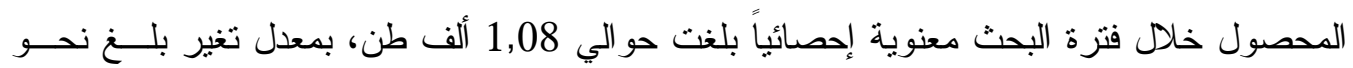

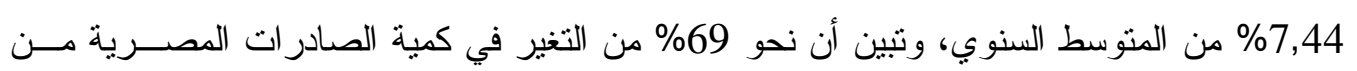

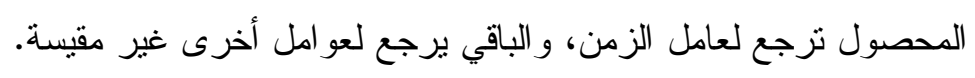




\section{جدول (4)}

الاتجاه الزمنى العام لتطور بعض المؤشرات الاقتصادية لمحصول الماتجو المثمر

بمصر خلال القترة (2000- 2016)

\begin{tabular}{|c|c|c|c|c|c|}
\hline المعنو & معدل التغير السنوي & السنويط & 2, & معادلة الاتجاه الزمني العام & البيان \\
\hline مغنوي & 8.27 & 136.4 & 0.98 & 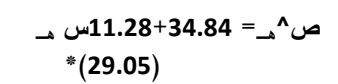 & المساحة المثمرة بالألف \\
\hline معنوي & 1.19 & 4.2 & 0.22 & 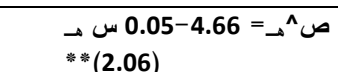 & الإتتاجية الفدانية بالطن \\
\hline مغنوي & 7.44 & 560.3 & 0.89 & 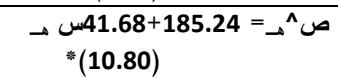 & كمية الإلتاج المحلي \\
\hline مغنوي & 7.26 & 544.8 & 0.88 & 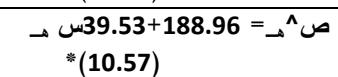 & الاستهلاك بالألف طن \\
\hline معنوي & 16.88 & 6.4 & 0.69 & 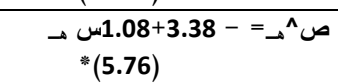 & كمية/الصادرات المصرية \\
\hline
\end{tabular}

ص^هـ المتغير التابع المقدر (المساحة بالألف فدان، الإتتاجية بالطن، الإتاج بالألف طن، الاستهلاك بالألف طن، الصادرات بالألف طن) للسنة هـ.

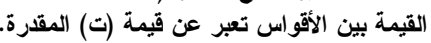

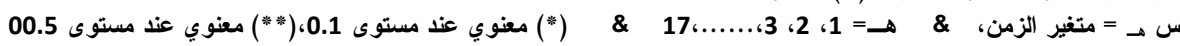

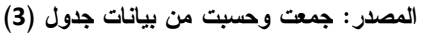

\section{التوزيع الجغر افى للمساحة المثرة لمحصول الماتجو فى مصر :}

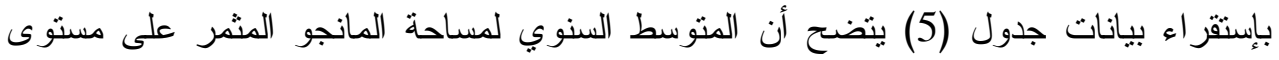

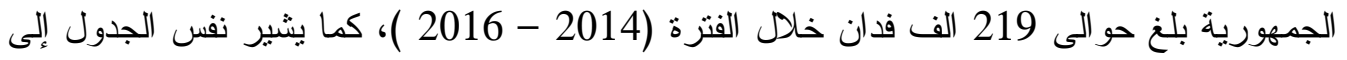
أن المتوسط السنوي للمساحة المثمرة للمانجو في محافظات الوجه البحرى بلغ حو الى 148 الف فدان

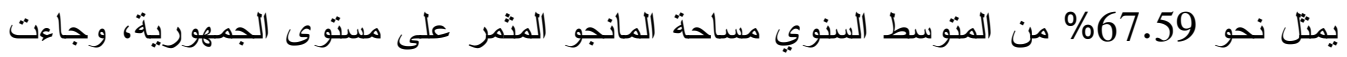

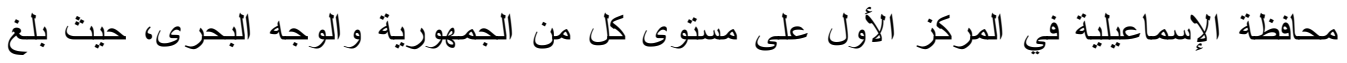

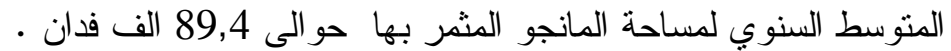
يمثل نحو 40.82\% ، 60.38 \% من المتوسط السنوي للمساحة المثمرة للجمهورية و الوجه البحرى

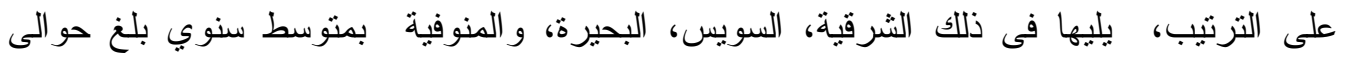

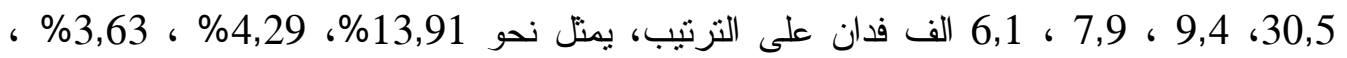
2,77\% المتوسط السنوي للمساحة المثمرة للجمهورية، ونحو 20,58\%، 6,34\%، 5,37\%، 4,10\% من المنوسط السنوي للمساحة المثرة للوجه البحري، و اتضح من نفس الجدول ان محافظة

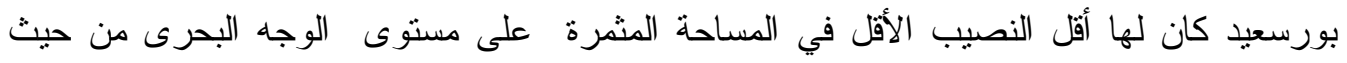
المتوسط السنوي للمساحة المثمرة بهذه المحافظة حو الى 0.01 الف فدان تمنل حو الى 0.005 \% ، 0.008\% من المتوسط السنوي للمساحة المثرة للجمهورية والوجه البحرى على الترتيب. أما بالنسبة لمحافظات مصر الوسطى فيشير الجدول السابق إلى أن المتوسط السنوي للمساحة

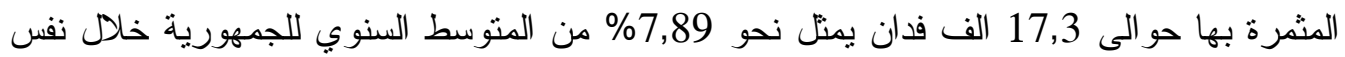
الفترة، وجاءت كل من الفيوم والجيزة لتمثل اعلى محافظات مصر الوسطى في المساحة المثرة بالمانجو بمتوسط بلغ حوالى 7,7، 7,6 الف فدان بنحو 3,65,52\% ، 3,47\% المتوسط السنوي للمساحة

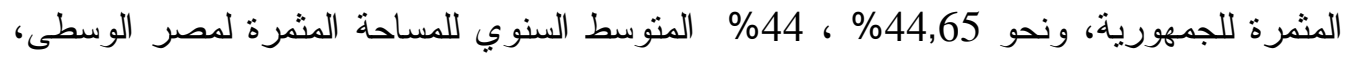
وتنين من الجدول أن المركز الأخير لمحافظات مصر الوسطى كان من نصيب محافظة بني سويف حيث بلغ المتوسط السنوي بها حوالى 0,5 الف فدان يمنل نحو 0,25\% ، 3,14\% من منوسط 
يتضح من بيانات نفس الجدول أن المتوسط السنوي للمساحة المثرة لمحافظات مصر العليا بلغ حوالى 13,8 الف فدان يمتل نحو 6,32\% من المتوسط السنوي لمساحة المانجو المثمر

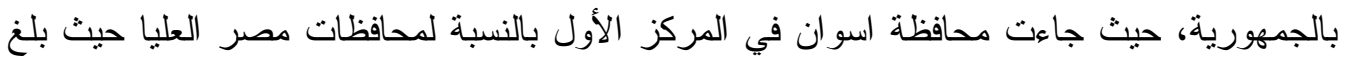

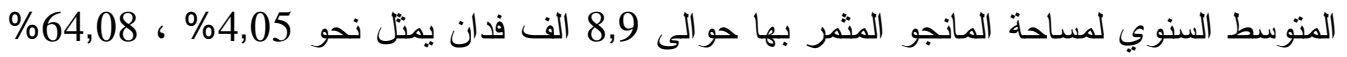
من المتوسط السنوي للمساحة المثرة للجمهورية و مصر العليا على الترتيب، و احتلت محافظة لهنة

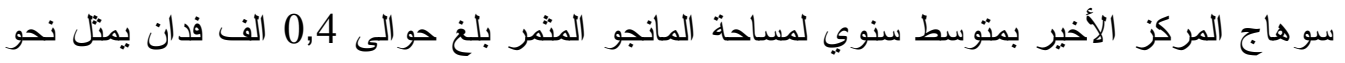

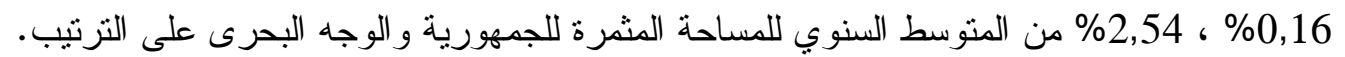

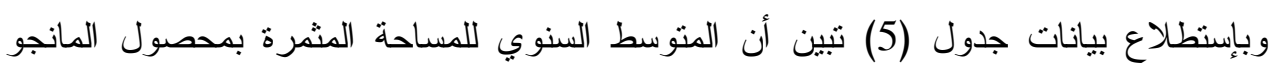

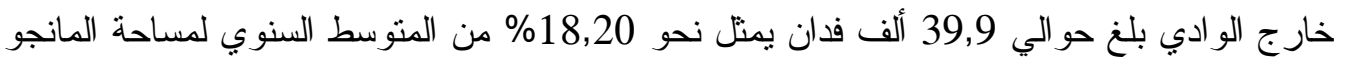

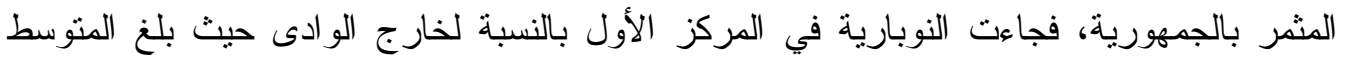

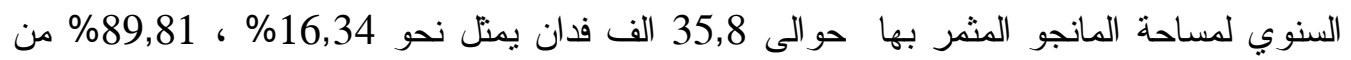

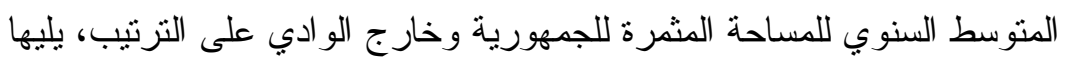

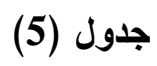

التوزيع الجغرافي لمساحة المانجو المثرة بمحافظات مصر خلال الفترة (2016-2014)

\begin{tabular}{|c|c|c|c|}
\hline \% من الجمهورية & \% من الوجه & مساحة المانجو المثمرة & حافظات \\
\hline 0.03 & 0.04 & 0.1 & الإنســـــندرية \\
\hline 3.63 & 5.37 & 7.9 & البحــــيرة \\
\hline 0.13 & 0.20 & 0.3 & الغربيــــــــة \\
\hline 0.05 & 0.07 & 0.1 & كفر الثيـــــــخ \\
\hline 0.02 & 0.03 & 0.04 & الدقهلي لــــة \\
\hline 0.48 & 0.71 & 1.1 & دميــــاط \\
\hline 13.91 & 20.58 & 30.5 & الثــــــرقية \\
\hline 40.82 & 60.38 & 89.4 & الإنــــاعيلية \\
\hline 0.008 & 0.005 & 0.01 & بــور ســـعيد \\
\hline 4.29 & 6.34 & 9.4 & 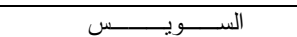 \\
\hline 2.77 & 4.10 & 6.1 & 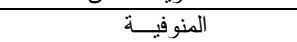 \\
\hline 0.36 & 0.53 & 0.8 & القليوبيـــــــة \\
\hline 1.10 & 1.63 & 2.4 & 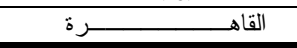 \\
\hline 67.59 & 100.00 & 148.0 & جملة الوجه البحرى \\
\hline 3.47 & 44.00 & 7.6 & الجيـــزة \\
\hline 0.25 & 3.14 & 0.5 & بنى ســـويف \\
\hline 3.52 & 44.65 & 7.7 & الفيب ــــوم \\
\hline 0.65 & 8.21 & 1.4 & المنيــــــا \\
\hline 7.89 & 100.00 & 17.3 & جملة مصر الوسطى \\
\hline 0.91 & 14.44 & 2.0 & أســـــوط \\
\hline 0.16 & 2.54 & 0.4 & ســــوهاج \\
\hline 0.32 & 5.13 & 0.7 & ق \\
\hline 0.87 & 13.82 & 1.9 & الأقصــــــر \\
\hline 4.05 & 64.08 & 8.9 & أســــــــوان \\
\hline 6.32 & 100.00 & 13.8 & جملة مصر العليا \\
\hline 81.80 & - & 179.1 & إجمالى داخل الو ادى \\
\hline 1.59 & 8.72 & 3.5 & الو ادى الجديد \\
\hline 0.001 & 0.01 & 0.003 & مط مـروح \\
\hline 0.15 & 0.84 & 0.3 & شمال ســيناء \\
\hline 0.11 & 0.62 & 0.2 & جنوب ســبناء \\
\hline 16.34 & 89.81 & 35.8 & النوباريـــــــة \\
\hline 18.20 & 100.00 & 39.9 & إجمالى خارج الو ادى \\
\hline 100.00 & - & 219.0 & الإجمــالى \\
\hline
\end{tabular}


في ذلك محافظة الو ادى الجديد بمتوسط سنوي بلغ حو الى 3,5 الف فــدان بنحـــ 1,59\%،

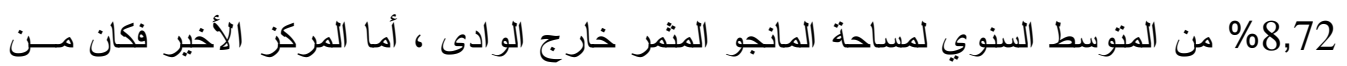

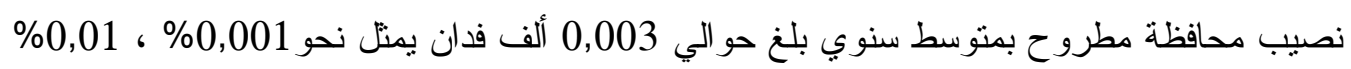

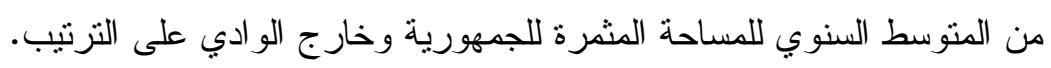

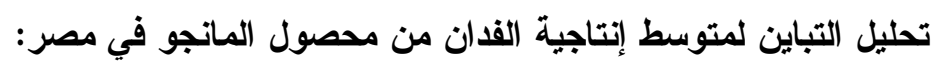

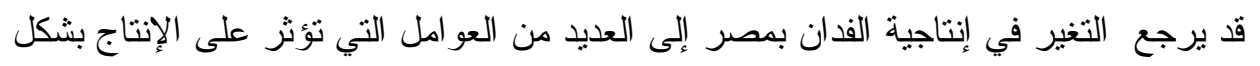

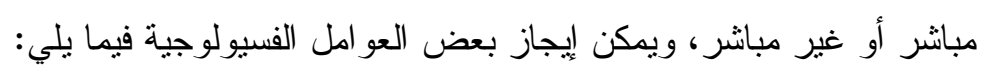
1

و المقصود به أن الحمل (الإنتاج) يكون كتيف فى موسم ما و يقل فى الموسم التالى أى ان

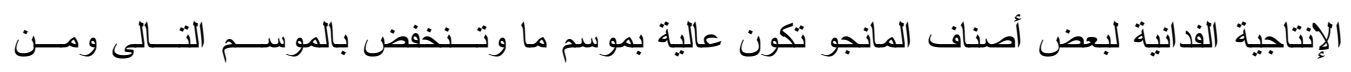
الأصناف كثيفة الحمل الزبدة و لانجر ا ومن الأصناف متوسطة الحمل المبروكة وقلب الثنور و والفونسو

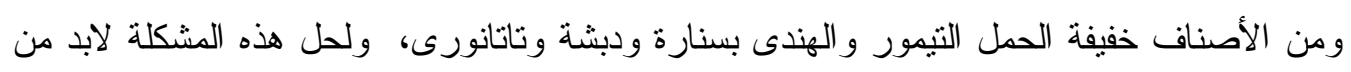
زر اعة أصناف منتظمة الحمل وإتباع برنامج سمادي مناسب و إستخدام التقليم. 2- مشكلة التشوه الخضري و الزهري:

يمكن حل هذه المشكلة عن طريق زر اعة الأصناف قلبلة الإصابة و القيام بعملية التقليم.

\section{3- مشكلة التزهير وعدم الإثمار:}

تعني أن الأشجار تعطي تزهير جيد و لا تعطى ثمار أو تعطي ثمار قليلة و السبب يرجــ الإنمار: الـى ان

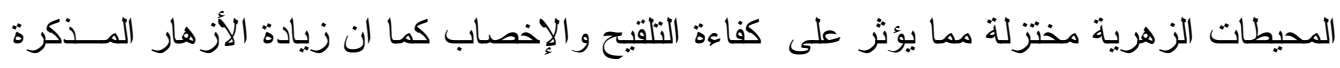

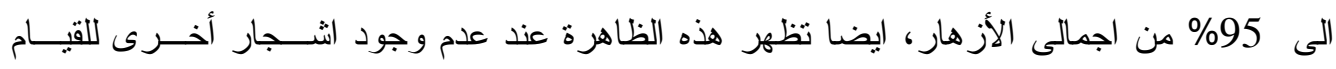

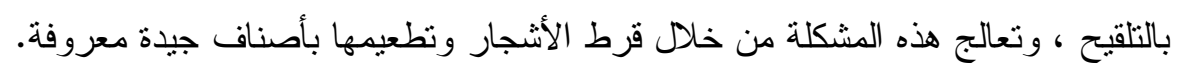
4-مشكلة تساقط الثمار:

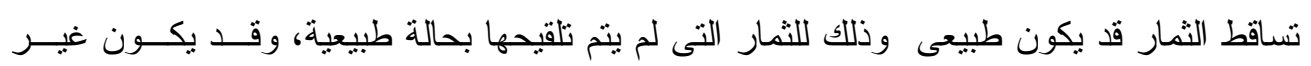

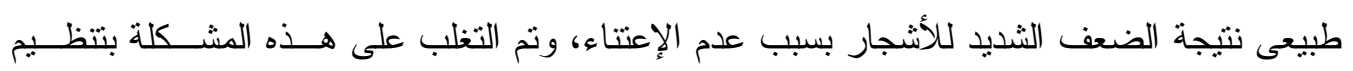

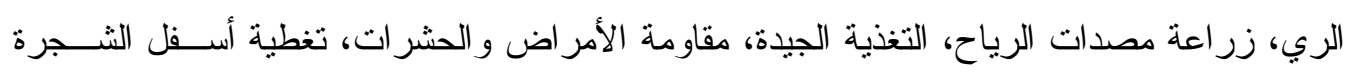

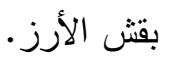

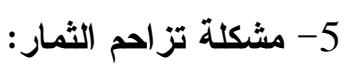

لتفادي هذه المشكلة يتم إجر اء التقليم وتجديد شباب الأشجار وخف الأشجار إن لزم الأمر . فضلاً عن العوامل الاقتصادية التى تؤثز فى محصول المانجو مثل زيادة التكاليف الانتاجية

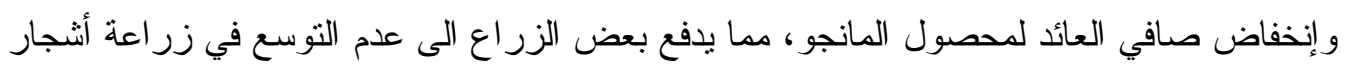

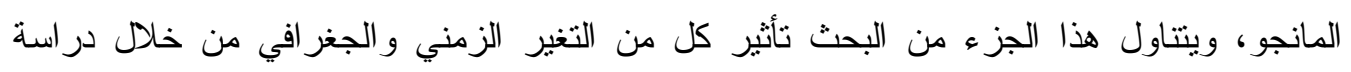
تحليل التباين للإنتاجية الفدانية لبعض المحافظات بإستخدام إختبار دنكان، حيث تنبين من البيانات الو اردة بجدول (6) عدم وجود إختلاف معنوي بين إنتاجية الفدان من المانجو خلال الفترة (2012 - 


\section{جدول(6)}

تحليل التباين للفروق بين متوسطات إنتاجية للمانجو خلا الفترة (2012 - 2016)

\begin{tabular}{|c|c|c|c|c|c|}
\hline المعنوية & $\mathrm{F}$ & $\begin{array}{c}\text { متوسط مربعات } \\
\text { الإنحر افات } \\
\text { (M.S) }\end{array}$ & $\begin{array}{c}\text { مجموع مربعات } \\
\text { الإنحر افات } \\
\text { (S.S) }\end{array}$ & درجات الحرية & مصدر التباين \\
\hline$m * *$ & 0.26 & 0.54 & 2.17 & 4 & بين السنو ات \\
\hline \multirow[t]{3}{*}{ " } & 7.24 & 2.51 & 27.62 & 11 & بين المحافظات \\
\hline & & 0.20 & 19.26 & 97 & الخطأ العشو ائي \\
\hline & & & 59.05 & 112 & الإجمالي \\
\hline
\end{tabular}

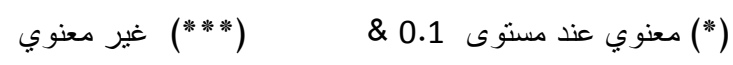

المصدر : جمعت و حسبت من بيانات جدول (3).

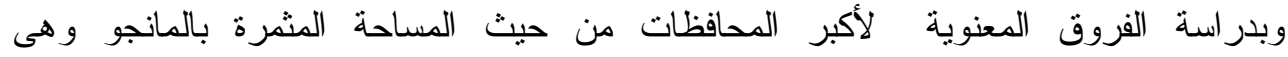
الإسماعيلية، منطقة النوبارية، الشرقية، السويس، أسوان، البحيرة، الفيوم، الجيزة، المنوفية، الوادي لوني الجديد، القاهرة، أسيوط و التي بلغ متوسطها السنوي حوالي 89,4، 35,8، 30,5، 9,4، 7,7، 7,6، 6,1، 3,5، 2,4، 2,0 ألف فدان على الترتيب.

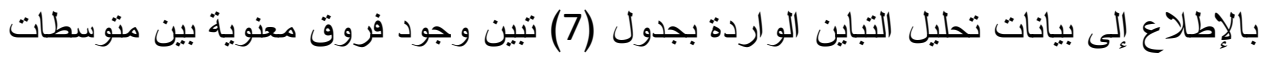
إنتاجية الفدان من المانجو في المحافظات، قد يكون السبب في ذلك هو إختلاف الأصناف المزروعة، وللتعرف على مدى معنوية هذه الفروق فقد تم استخدام طريق دنكان لإختبار أقل فرق معنوي بين

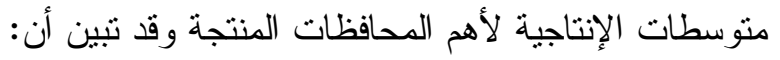
1- هناك فروق معنوية بين محافظة النوبارية وهى أعلى المحافظات إنتاجية (7,23 طن للفدان)،

$$
\text { وبين جميع المحافظات المدروسة. }
$$

2- يوجد إختلافات معنوية بين محافظة الوادي الجديد وهى ثاني المحافظات في الإنتاجية 5 (5,09 طن/فدان)، وبين الفيوم، أسوان، القاهرة، الجيزة، الإسماعيلية، و المنوفية، عدا محافظة البحيرة

$$
\text { فلا توجد فروق معنوية. }
$$

3- يوجد فروق معنوية بين محافظة البحيرة وهى ثالث المحافظات في الإنتاجية (5,04 طن/فدان)، وبين القاهرة، الجيزة، الإسماعيلية، و المنوفية، وبين جميع المحافظات المدروسة، ولهين ولا توجد فروق معنوية بينها وبين الثرقية. 4 كما تبين وجود فروق معنوية بين محافظة الثرقية، وبين جميع المحافظات المدروسة، عدا وبنا محافظة أسيوط فلا توجد فروق معنوية. 


\section{جدول (7) (7)}

معنوية الفروق بين متوسطات إنتاجية المانجو لأهم المحافظات المنتجة باستخدام طريقة دنكان خلا الفترة (2016-2012)

\begin{tabular}{|c|c|c|c|c|c|c|c|c|c|c|c|c|}
\hline 2.68 & 3.00 & 3.16 & 3.38 & 3.55 & 3.78 & 3.83 & 4.09 & 4.51 & 5.04 & 5.09 & 7.23 & م.الإنتادية: \\
\hline المنوفيـة & الإسماعيلية & الجيـزة & القاهر: & أســـوان & الفبـــرم & السوبس & أسيوط & الشُرَقِية & البديزة & الو ادى الجليد & النوبارية & المدافظات \\
\hline${ }^{\prime} 4,26$ & 4,07 & 3,87 & 3,84 & 3,67 & 3,62 & '3,46 & 3,24 & 3,07 & 2,97 & · 2,62 & - & النوبارية \\
\hline '3,06 & 3,01 & '2,64 & 2,62 & "2,26 & "2,32 & '2,82 & 2,73 & " 2,28 & 1,17 & - & & الوا ادى \\
\hline & & & & & & & & & & & & \\
\hline 3,03 & 2,88 & " 2,17 & "2,57 & 2,17 & "2,14 & 2,62 & "2,46 & 1,14 & - & & & لبديرة" \\
\hline${ }^{\prime} 2,87$ & 2,71 & "2,05 & " 2,43 & "2,11 & " 2,08 & $\cdot 2,59$ & 1,27 & - & & & & الشَــرنة \\
\hline${ }^{\prime}, 62$ & " 2,44 & "2,01 & ${ }^{\prime} 2,19$ & "2,06 & 1,77 & 1,66 & - & & & & & لسـبروط \\
\hline "2,23 & $" 2,36$ & 1,34 & 1,87 & 1,83 & 1,43 & - & & & & & & السـريــس \\
\hline "2,04 & 1,42 & 1,18 & 1,71 & 1,56 & - & & & & & & & الفيـــرم \\
\hline 1,89 & 2,14 & 1,02 & 0,97 & - & & & & & & & & أســـــران \\
\hline 1,78 & 1,19 & 0,73 & - & & & & & & & & & القاهــرة \\
\hline 1,60 & 0,64 & - & & & & & & & & & & الجيزة \\
\hline 1,09 & - & & & & & & & & & & & الإسطاعليلة \\
\hline - & & & & & & & & & & & & المنوفيـــــة \\
\hline 1,64 & 1,79 & 1,80 & 1,86 & 1,91 & 1,95 & 1,98 & 2,04 & 2,06 & 2,07 & 2,08 & 2,09 & L.S.R \\
\hline 1,27 & 1,35 & 1,42 & 1,45 & 1,47 & 1,50 & 1,52 & 1,57 & 1,58 & 1,60 & 1,61 & 1,62 & $L, S, R 0,5$ \\
\hline
\end{tabular}

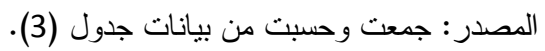

أثر التغير فى المساحة المثمرة والإتتاجية الفدانية على إنتاح محصول المانجو في مصر :

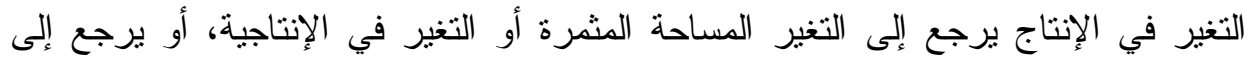
عوامل آخرى ولقياس أثز التغير المساحة المثمرة و الإنتاجية لمحصول المانجو تم مقارنة متوسط الفترة (2016-2014) بمنوسط الفترة (2002-2000) ، من خلال استخدام المعادلات التالية:

$$
\text { 1- التغير في الإنتاج الكلي راجع للمساحة المثرة }
$$

التغير في المساحة المثمرة خلال الفترتين X منوسط الإنتاجية خلال الفترة الأولى.

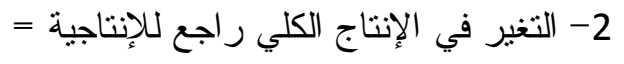

متوسط المساحة المثمرة خلا الفترة الأولى X التغير في الإنتاج خلال الفترتين.

3- التغير في الإنتاج الكلي راجع للمساحة المثمرة والإنتاج = التغير في منوسط المساحة المثرة X التغير في منوسط الإنتاجية الفدانية. 5-التغير الكلى في الإنتاجية الفدانية هو مجموع التغير ات السابقة. 


\section{جدول(8)}

أثز التغير في المساحة المثمرة و الإتتاجية القدانية على إنتاج المانجو

\begin{tabular}{|c|c|c|c|c|}
\hline$\%$ & الإنتاج الكلي بالألف & بالطاجية الفدانية & الكالاحف فدان المثرة & البيان \\
\hline- & 303,90 & 4,57 & 66,37 & متوسط الفترة الأولى (2000-2002) \\
\hline- & 923,23 & 4,20 & 219 & متوسط الفترة الثانية \\
\hline- & 619,33 & $(0,37)$ & 152,63 & التغير في الفترتين \\
\hline 113,14 & 697,52 & - & - & اللتغير في الإلتاج راحة التع \\
\hline$(3,98)$ & $(24,56)$ & - & - & اللتغير في الإنتاج راجع \\
\hline$(9,16)$ & $(56,47)$ & - & - & 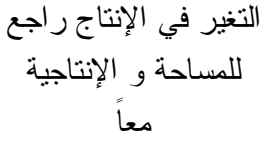 \\
\hline 100 & 616,49 & - & - & التغير الكلي \\
\hline
\end{tabular}

الأرقام ما بين الأقو اس تثير إلى قيم سالبة.

المصدر : جمعت و حسبت من بيانات جدول (3).

وبإستقر اء بيانات جدول (8) تبين أن تأثثر كلاً من زيادة المساحة المثرة وإنة إنخفاض الإنتاجية الفدانية معاً خلال الفترتان (2002-2000)، (2016-2014) أدى إلى إنخفاض الإنتاج بحو الي المانجو خلال فترنى البحث بلغ حوالى 616,49 ألف طن، ويرجع هذا التغير الى التغير فى إنتاج

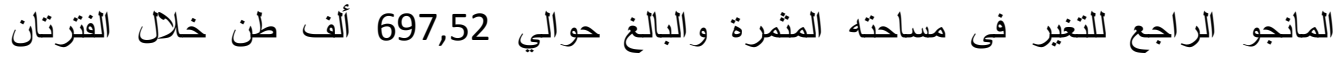
المدروستان، بينما أدى إنخفاض إنتاجية الفدان من المحصول خلال فترتي البحث ولثي إلى إنخفاض الإنتاج بحو الي 24,56 ألف طن يمثل نحو 3,98\% من التغير الكلى في الإنتاج.

\section{الإستقرار الإتتاجي والتصديري لمصر والدول المنافسة:}

يتضح من بيانات جدول (9) مدى الإستقر ار الإنتاجي و التصديري لمصر و الدول المنافسة للمانجو

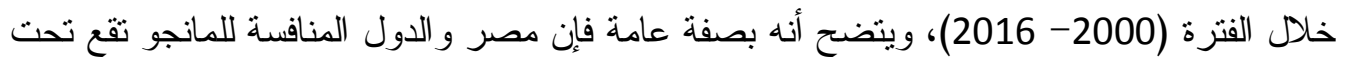
عدم الإستقر ار الإنتاجي، لأن قيمة هذا المؤشر تبتعد عن الصفر حيث نراوح أدنى قيمة (72) بالنسبة

$$
\text { مصر ، و أعلى قيمة (142) بالنسبة لهولندا. }
$$

يثير الجدول نفسه إلى أن مصر تتمتع بإستقرار إنتاجي بلغ قيمته (72) بالمقارنة بكل دول

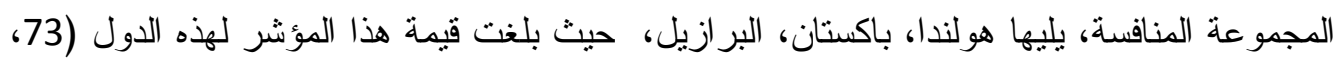

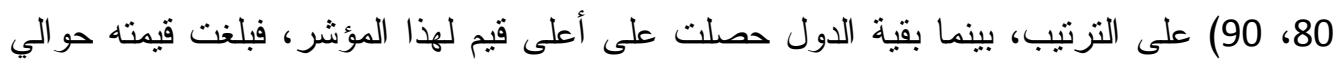

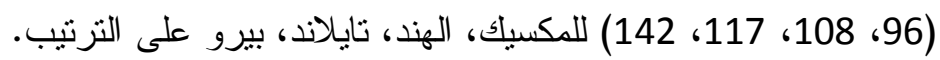


أما بالنسبة للإستقر ار التصديري فحصلت مصر على أدنى مستوى من بين المجموعة المنافسة ،

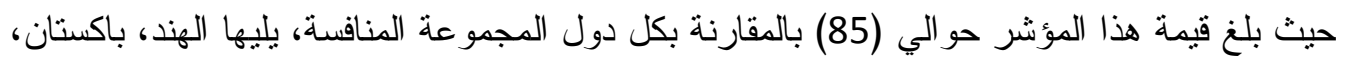

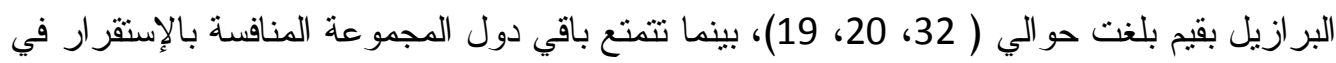

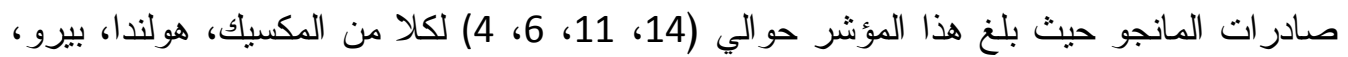
تايلاند على الترنيب.

يتبين مما سبق أنه على الرغم من أن هناكل ميزة لدصر في الإستقرار الإنتاجي لمحصول

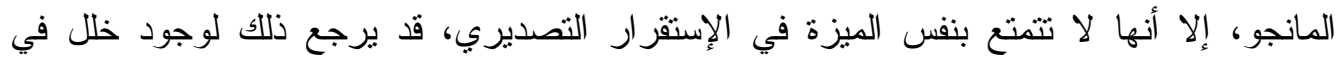

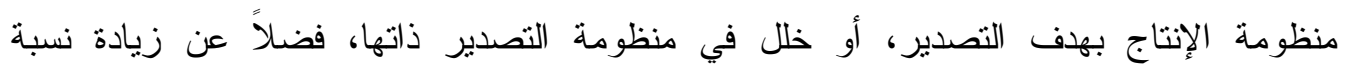
الاستهلاك المحلي من الإنتاج حيث بلغت هذه النسبة نحو 97\%، وعلى العكس من ذلك نبين من البحث أن المكسيك، بيرو، هولندا لها ميزة في الإسنقر ار التصديري، وقد يرجع إلى أن هذه الدول تتنهج سياسات تصديرية جيدة تقوم على الإحتفاظ بحصنها السوقية. جدول(9) بدأ)

نتائج معاملات الاستقزار الإتتاجي والتصديري لمصر وأهم الدول المنافسة للمانجو

\section{خلال الفترة (2000- 2016)}

\begin{tabular}{|c|c|c|}
\hline معامل عدم إستقر ار كمية & معامل عدم إستقر ار كمية الإنتاج & المؤشر \\
\hline 14 & 96 & المكسيك \\
\hline 32 & 108 & الهند \\
\hline 19 & 90 & البر ازيل \\
\hline 4 & 117 & تايلاند \\
\hline 11 & 73 & هو لندا \\
\hline 6 & 142 & بيرو \\
\hline 20 & 80 & باكستان \\
\hline 85 & 72 & مصر \\
\hline
\end{tabular}

المصدر : حسب من جدول (3) - (3)

الملخص و التوصيات

تبين من نتائج البحث أن المتوسط السنوي لقيمة الإنتاج الزر اعي، النباتي، الفاكهي، و المانجو بلغ حو الى 18,7، 108,5،18,5، 2 مليار جنيه على الترتيب خلال فترة البحث، وتمثل قيمة الإنتاج الفاكهي نحو 10,3\%، 17,9\% من قيمة الإنتاج الزر اعي والنباتي على النزتيب، وتمثل قيمة إنتاج المانجو نحو 1,1\%، 1,9\%، 10,5\% من المتوسط السنوي لكل من قيمة الإنتاج الزراعي، قيمة الإنتاج النباتي، قيمة الإنتاج الفاكهي لنفس الفترة على النزتيب. وقد بلغ المتوسط السنوي للمساحة المثمرة، الإنتاجية الفدانية، الإنتاج للمانجو خلال الفترة (2000- 2016) حوالي 136,4ألف فدان، 4,2 طن للفدان، 560,3 ألف طن، بزيادة سنوية في الإنية 
المساحة و الإنتاج بلغت حو الي 11,28 ألف فدان، 41,68 ألف طن بينما يوجد نتاقص سنوي معنوي في الإنتاجية الفدانية للمحصول خلاجل فترة البحث بلغ حو الي 0,05 طن للفدان.

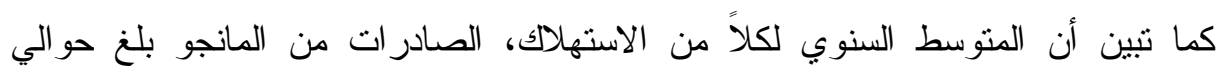

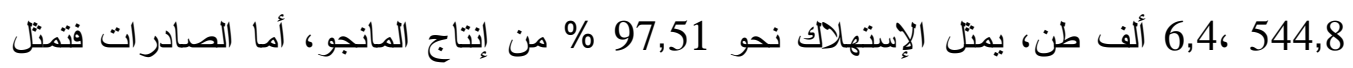

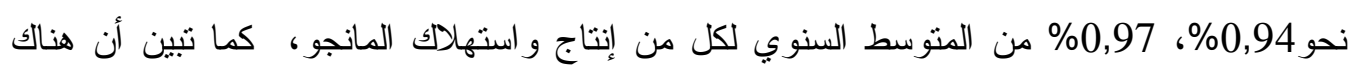
زيادة سنوية في الاستهلاك و الصادرات من المانجو بلغت حو الي 39, 39,53، 1,08 ألف طن .

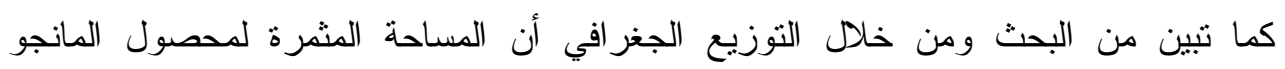
بمحافظات مصر خلا الفترة (2016-2014) أن أكبر المحافظات من حيث المساحة المن المثرة بالمانجو هى الإسماعيلية، النوبارية، الشرقية، السويس، أسوان، البحيرة، الفيوم، الجيزة، المنوفية، الو ادي الجديد، القاهرة، أسيوط و التني بلغ المنوسط السنوي لمساحاتها المثمرة حوالي

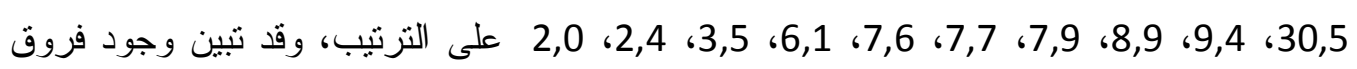
معنوية بين متوسطات إنتاجية الفدان من المانجو لنلاك المحافظات. كما اتضح من نتائج البحث أن التغير الكلى في إنتاج المانجو خلاد الفترن الفتان (2000-

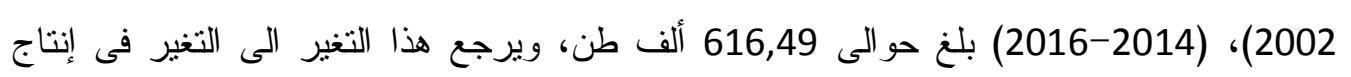

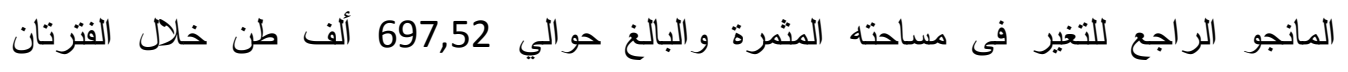
المدروستان، بينما أدى إنخفاض إنتاجية الفدان من المحصول خلال فترتي البحث الى فئ إنخفاض

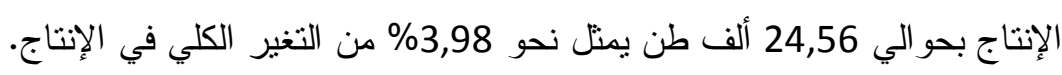

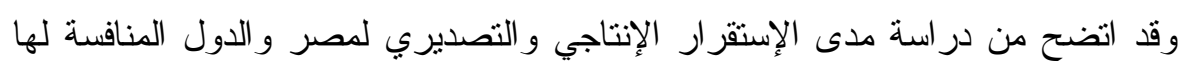

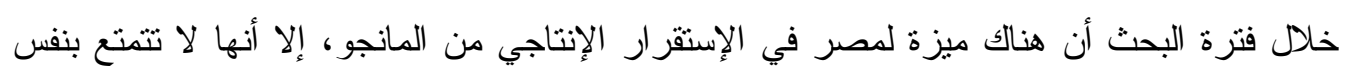

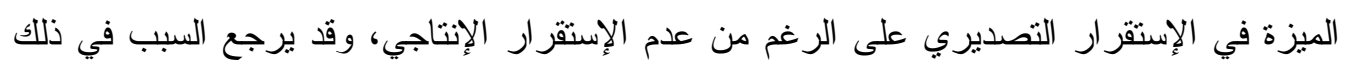

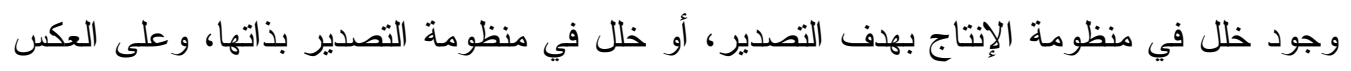

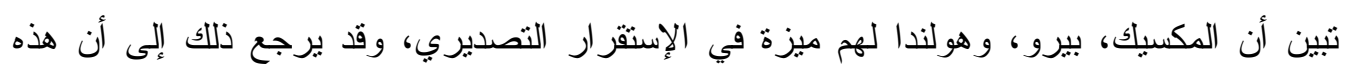
الدول نتنهج سياسات تصديرية جيدة نقوم على الإحتفاظ بحصنها السوقية. التوصيات

1- إستتباط أصناف مطابقة لمو اصفات التصدير لزيادة حصة مصر في الصادر ات و القدرة على لئى

$$
\text { المنافسة في الأسواق العالمية. }
$$

2- التوجه لزيادة المساحة المزروعة في المناطق عالية الإنتاجية لتحقيق أعلى عائد للمزارع.

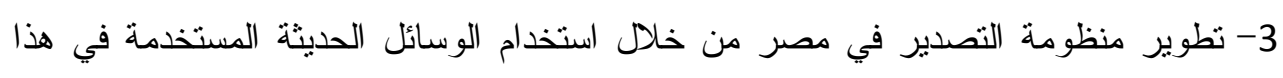
المجال.

4- تشجيع المزارعين على زراعة هذا المحصول من خلا حزمة من المساعدات المقدمة للمز ارعين. (- مين. 


\section{المراجع}

1- الجهاز المركزي للتعبئة العامة والإحصاء، قاعدة بيانات التجارة الخارجية.

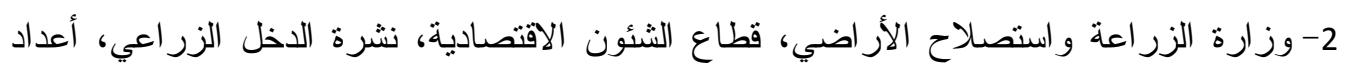
مختلفة.

3-وزارة الزراعة واسنصلاح الأراضي، قطاع الشئون الاقتصادية، الإدارة المركزية للاقتصاد

$$
\text { الزر اعي، بيانات منشورة. }
$$

4- وز ارة الزر اعة، قطاع الثئون الاقتصادية، نشرة الميزان الغذائي، بيانات منشورة.

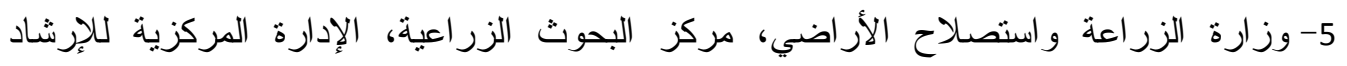

$$
\text { الزر اعي و البيئي. }
$$

6- حنان عبد المجيد محمودالامير " دراسة اقتصادية لمحصول المانجو بمحافظة الاسماعيلية "،

$$
\text { مجلة جامعة المنصورة للعلوم الزر اعية، مجلد (4)، العدد (8)، مايو } 2012 \text { ـ }
$$

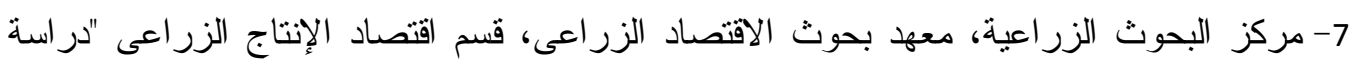

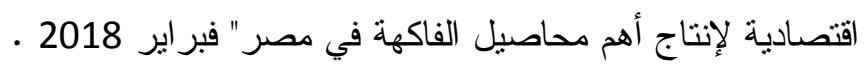

